\title{
Peran Kualitas Pelayanan Penyedia Internet Terhadap Kepuasan Pelanggan
}

\author{
Ayu Marluthy ${ }^{1 *}$ dan Ii Halilah ${ }^{2}$ \\ 1Jurusan Administrasi Niaga, Politeknik Negeri Bandung, Indonesia \\ 2Jurusan Administrasi Niaga, Politeknik Negeri Bandung, Indonesia
}

\begin{abstract}
:
This study aims to determine how much influence the quality of internet provider service to customer satisfaction, using linear regression analysis. The population in this study is the people of Bandung who use or subscribe internet access. Sampling technique used is non-probability sampling by taking samples using quota. The sample of research is 100 respondents. Data collection techniques using observation techniques and questionnaire. The amount of influence service quality to customer satisfaction that is equal to 0,538 or 53,8\% change of customer satisfaction can be explained by service quality variable, while the rest equal to 46,2\% explained by cause or other factor not examined.
\end{abstract}

Keywords: customer satisfaction, consumers, service quality

\begin{abstract}
Abstrak:
Penelitian ini bertujuan untuk mengetahui seberapa besar pengaruh kualitas layanan penyedia internet terhadap kepuasan pelanggan, menggunakan analisis regresi linier. Populasi dalam penelitian ini adalah masyarakat Bandung yang menggunakan atau berlangganan akses internet. Teknik pengambilan sampel yang digunakan adalah non-probability sampling dengan mengambil sampel menggunakan kuota. Sampel penelitian adalah 100 responden. Teknik pengumpulan data menggunakan teknik observasi dan kuesioner. Besarnya pengaruh kualitas layanan terhadap kepuasan pelanggan yaitu sebesar 0,538 atau $53,8 \%$ perubahan kepuasan pelanggan dapat dijelaskan oleh variabel kualitas layanan, sedangkan sisanya sebesar 46,2\% dijelaskan oleh sebab atau faktor lain yang tidak diteliti.
\end{abstract}

Kata Kunci: kepuasan pelanggan, konsumen, kualitas layanan

\section{Pendahuluan}

Dalam berbisnis diperlukan produk yang berkualitas untuk dipasarkan sehingga dapat menguntungkan bagi perusahaan, hal ini sesuai dengan yang dikatakan Griffin dan Ebert (dalam Nugroho, 2015) bahwa definisi bisnis adalah suatu kegiatan menyediakan barang atau jasa yang dibutuhkan oleh pelanggan untuk mendapatkan laba. Pada era globalisasi ini, produk dan jasa yang bersaing dalam satu pasar semakin banyak dan beragam. Sehingga terjadilah persaingan antarprodusen untuk dapat memenuhi kebutuhan pelanggan serta memberikan kepuasan kepada pelanggan secara maksimal, karena pada dasarnya tujuan dari suatu bisnis salah satunya adalah untuk menciptakan rasa puas pada pelanggan. Salah satu tindakan untuk memuaskan pelanggan adalah dengan cara memberikan pelayanan kepada 
pelanggan dengan sebaik-baiknya. Terdapat beberapa hal yang dapat memberikan kepuasan pelanggan, menurut Kotler (dalam Saputro dkk, 2016) yaitu nilai total pelanggan yang terdiri dari nilai produk, nilai pelayanan, nilai personal, nilai image atau citra, dan total biaya pelanggan yang terdiri dari biaya moneter, biaya waktu, biaya tenaga, dan biaya pikiran.

Jika perusahaan memberikan pelayanan yang baik kepada pelanggannya, maka akan menciptakan kepuasan bagi pelanggannya. setelah pelanggan merasa puas dengan produk atau jasa yang diterimanya, pelanggan akan menilai pelayanan yang telah diberikan oleh perusahaan tersebut dengan pelayanan di perusahaan lainnya. Apabila pelanggan merasa benar-benar puas, mereka akan melakukan pembelian

Tabel 1. Market Share Penyedia Internet Tahun 2016-2018

\begin{tabular}{lllll}
\hline \multirow{2}{*}{ Merk } & \multicolumn{2}{l}{ Market } & Share $\mathbf{( \% )}$ & Kenaikan \\
\cline { 2 - 5 } & $\mathbf{2 0 1 6}$ & $\mathbf{2 0 1 7}$ & $\mathbf{2 0 1 8}$ & $(\mathbf{\%})$ \\
\hline Indihome & $48,1 \%$ & $50,3 \%$ & $42,1 \%$ & $6 \%$ \\
Biznet.Net & - & $2,1 \%$ & $6,4 \%$ & $4,3 \%$ \\
First Media/ FastNet & $18,6 \%$ & $17,3 \%$ & $22,4 \%$ & $3,8 \%$ \\
Telkomnet Instant & $4,7 \%$ & - & - & $0 \%$
\end{tabular}

ulang serta merekomendasikan produk tersebut kepada orang lain agar membeli di tempat yang sama. Oleh karena itu menurut Tjiptono (2015) perusahaan harus memiliki pelayanan yang prima untuk memuaskan pelanggan sehingga kesan yang baik akan tercipta dan tentunya akan menguntungkan bagi perusahaan kelak.

Pelayanan berkualitas yang diberikan oleh perusahaan diperlukan untuk menarik keputusan pembelian dan mencapai tingkat kepuasan pelanggan. Peningkatan kualitas pelayanan yang dilakukan secara terus-menerus merupakan salah satu strategi yang dapat menguntungkan perusahaan penyedia jasa atau barang dan pelanggannya. Sehingga dari hal tersebut, dibutuhkan peningkatan teknik untuk menganalisis tingkat kepuasan pelanggan yang dapat dijadikan sebagai tolok ukur perusahaan dalam mengetahui kepuasan pelanggannya berada pada level yang mana. Kualitas pelayanan yang diberikan oleh perusahaan penyedia layanan atau barang, dapat menciptakan suatu persepsi positif dari pelanggan terhadap perusahaan penyedia jasa dan menghasilkan suatu kepuasan serta loyalitas dari pelanggan.

PT Telekomunikasi Indonesia yang berfokus pada bidang Telecommunication, Information, Media, Edutainment, dan Service yang disingkat menjadi (TIMES) menyiapkan produk seperti Indihome dan Wifi.ID untuk memfasilitasi masyarakat digital. Pertumbuhan pengguna internet yang meningkat dari tahun 1998 sampai tahun 2017 pada gambar 1 mengharuskan PT Telekomunikasi Indonesia membuat produk yang menggunakan internet sebagai sarana berbagi informasi. Produk tersebut adalah Indihome yang diluncurkan pada tahun 2015 untuk menghadapi persaingan di dunia bisnis yang semakin meningkat.

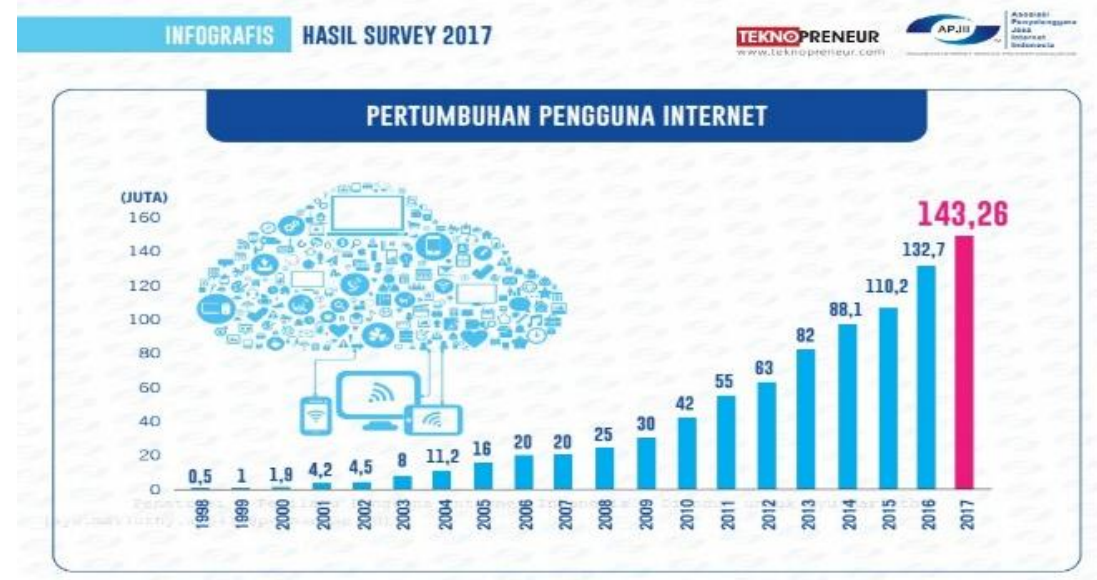

Sumber: Asosiasi Penyelenggara Jasa Internet Indonesia (APJII)

Gambar 1. Pertumbuhan Pengguna Internet di Indonesia 
Produk Indihome meliputi layanan tripleplay (3P) yaitu paket layanan komunikasi dan data seperti telepon rumah (Voice), internet (Internet on Fiber atau High Speed Internet), dan layanan televisi interaktif (Usee TV Cable, IPTV). Berdasarkan data yang diperoleh dari www.topbrand-award.com tentang market share Indihome selama tiga tahun terakhir menunjukkan pelanggan yang memilih untuk menggunakan produk Indihome terlihat fluktuatif atau tidak stabil yaitu naik turun, hal ini dapat dilihat pada tabel 1 bahwa dari 48,1\% tahun 2016 sempat naik menjadi 50,3\% tahun 2017 tetapi pada tahun 2018 mengalami penurunan menjadi 42,1\%. Sedangkan dibandingkan dengan pesaingnya yang lain seperti (First Media/FastNet, Biznet dan Telkomnet Instan) Indihome menguasai pangsa pasar layanan data dan TV berbayar selama tiga tahun terakhir. Data tersebut dapat memberitahukan bahwa secara umum Indihome belum bisa memenuhi harapan pelanggannya, karena penggunanya yang relatif naik turun dalam tiga tahun terakhir. Selain itu, pelanggan sering mengeluhkan kurangnya informasi yang disampaikan PT Telekomunikasi Indonesia mengenai jumlah tagihan yang harus dibayarkan, sedangkan pelanggan yang baru saja berlangganan satu atau dua bulan sudah meminta untuk dicabut karena sering terjadi gangguan. Keluhan tersebut dapat dibuktikan pada gambar 2.

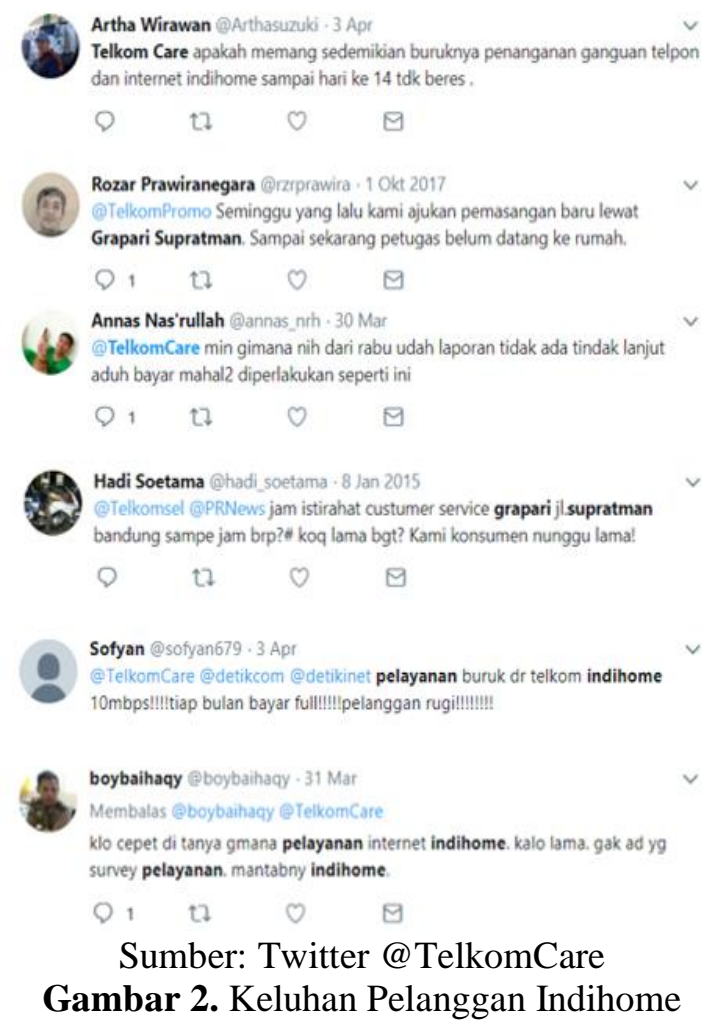

PT Telekomunikasi Indonesia menyediakan Grapari Plasa Telkom untuk memenuhi kewajibannya melayani pelanggan yang memiliki keluhan atas salah satu produknya yaitu Indihome. Namun banyak keluhan yang disampaikan pelanggan seperti Indihome yang sering mengalami gangguan dan proses penanganan gangguannya pun membutuhkan waktu lama sehingga pelanggan banyak meminta cabut layanannya. Permintaan cabut Indihome yang sudah berlangganan tentunya akan merugikan perusahaan karena dari sisi pendapatan pun akan berkurang.

Demi tercapainya kualitas pelayanan yang baik dan dapat memuaskan pelanggan sehingga mengurangi permintaan cabut, PT Telekomunikasi Indonesia Divisi Regional III Jawa Barat menyediakan pelayanan di Grapari Plasa Telkom Group yang ada di Jawa barat. Terdapat 11 Grapari Plasa Telkom Group yang tersebar di beberapa tempat di Jawa Barat seperti di Setiabudi, Supratman, Supratman, Rajawali, Cimahi, Karawang, Cirebon, Tasikmalaya, Sukabumi, Kuningan, dan Indramayu. Kesebelas plasa tersebut menangani pelayanan pasang baru, laporan gangguan, laporan keluhan, layanan informasi, pemintaan perubahan layanan, permintaan cabut, informasi tagihan, pembayaran di kasir, dan layanan quick service yang membutuhkan penanganan secara cepat atas keluhan yang disampaikan pelanggan. 
Grapari Plasa Supratman melayani informasi mengenai produk Indihome khususnya, pembayaran tagihan Indihome, menangani keluhan pelanggan mengenai gangguan serta melayani permintaan cabut Indihome dengan alasan seperti pindah alamat. Kualitas pelayanan yang diberikan PT Telekomunikasi Indonesia di Grapari Plasa Supratman sebaiknya dievaluasi agar dapat mengetahui sejauh mana pelanggan merasa puas. Dengan demikian, Grapari Plasa Supratman dapat meningkatkan kepuasan pelanggan atas kualitas layanan Indihome yang diberikan kepada pelanggan Indihome dan mengurangi permintaan cabut seperti yang diharapkan perusahaan.

Selanjutnya, peneliti melakukan wawancara terhadap 10 orang pengguna Indihome untuk mengetahui seberapa besar pelanggan yang merasa puas menggunakan Indihome dari segi pelayanan yang diberikan kepada pelanggan. Dari hasil wawancara menunjukkan bahwa 7 orang menyatakan kurang puas terhadap pelayanan yang diberikan PT Telekomunikasi Indonesia. Sehingga diperlukan penelitian untuk mengetahui penyebab ketidakpuasan pelanggan terhadap pelayanan yang diberikan PT Telekomunikasi Indonesia. Berdasarkan fenomena tersebut, penulis melakukan penelitian mengenai sejauh mana kualitas pelayanan dapat mempengaruhi kepuasan pelanggan layanan triple play (3P) yang dimiliki PT Telekomunikasi Indonesia yaitu Indihome.

\section{Kajian Literatur}

Kepuasan pelanggan menurut Ratnasari dan Aksa dalam Zakaria (2017:4) dapat dipengaruhi oleh beberapa variabel diantaranya kualitas pelayanan, kualitas produk, emosional, harga, dan biaya. Penelitian ini akan membahas salah satu variabel yang mempengaruhi kepuasan pelanggan yaitu kualitas pelayanan.

\subsection{Kualitas Pelayanan}

Pelayanan yang diberikan perusahaan harus berkualitas sehingga pelanggan akan merasa puas. Sejalan dengan hal itu Tjiptono (2012:15) mengatakan kualitas layanan adalah suatu kemampuan perusahaan untuk memenuhi kebutuhan dan keinginan pelanggan sesuai dengan yang diharapkan oleh pelanggan. Dengan kata lain, seberapa besar usaha perusahaan yang bersangkutan untuk dapat melayani pelanggannya sebaik mungkin seperti yang diharapkan mereka. Kemudian menurut Wijaya (dalam Putri dan Arry, 2016) bahwa kualitas pelayanan merupakan keseluruhan gabungan karakteristik yang dihasilkan dari pemeliharaan yang membuat produk dan jasa tersebut dapat digunakan untuk memenuhi harapan pelanggan.

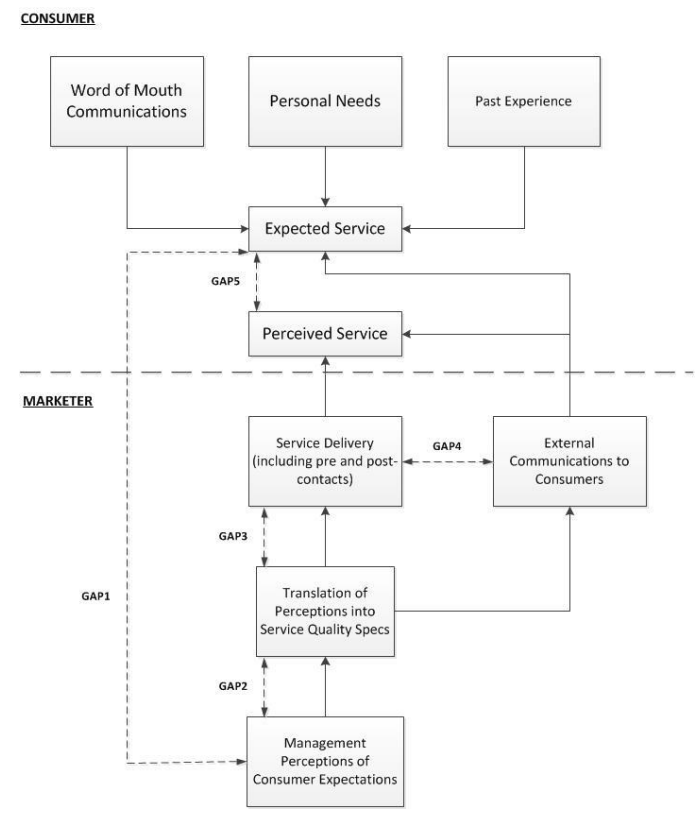

Sumber: Parasuraman et al. (1985:44)

Gambar 3. Model SERVQUAL

Menurut Parasuraman et al. (1991), perusahaan dapat memperoleh keunggulan kompetitif mereka dengan memanfaatkan teknologi untuk meningkatkan kualitas pelayanan yang diberikan dan memenuhi 
permintaan pasar. Kualitas pelayanan adalah harapan pelanggan yang menjelaskan bahwa pelanggan memiliki harapan dari penyedia layanan dan jika kualitas layanan yang dirasakan memenuhi atau melebihi harapan pelanggan, maka pelanggan akan senang dan jika kurang dari harapan pelanggan tersebut maka akan terciptanya kekecewaan yang mencirikan ketidakpuasan (Parasuraman: 1988).

Dari pemaparan di atas dapat ditarik kesimpulan bahwa kualitas pelayanan adalah suatu kemampuan perusahaan dalam memenuhi kebutuhan pelanggan dan memberikan pelayanan yang dapat memuaskan pelanggan baik dari segi pelayanan yang dirasakan atau pelayanan yang diharapkan oleh pelanggan. Baik atau buruknya kualitas pelayanan suatu perusahaan bergantung pada kemampuan penyedia jasa pelayanan dalam memenuhi harapan pelanggan secara baik dan konsisten.

Mengukur kualitas pelayanan dapat dilihat dengan membandingkan antara harapan (expectation) dan performansi (perceived) pelanggan dari suatu layanan jasa yang telah didapatkan. Metode SERVQUAL telah digunakan oleh berbagai peneliti sejak awal kemunculannya pada tahun 1985 oleh Parasuraman et al, menurutnya kualitas pelayanan dapat diukur dengan menghitung gap (celah/kesenjangan) antara harapan pelanggan dengan kenyataan yang telah didapatkan. Sedangkan menurut Ulkhaq (2017:62) metode SERVQUAL memiliki premis yang mengatakan bahwa pelanggan dapat dianggap puas jika kinerja dari layanan jasa yang diberikan telah melebihi harapan pelanggan tersebut. Gap tersebut dijelaskan pada gambar 3 yang dikemukakan oleh Parasuraman et al (1985:44).

Kelima gap yang ada dalam metode SERVQUAL pada gambar 3 akan dijelaskan sebagai berikut, Gap 1 menunjukkan kesenjangan atau gap yang terjadi antara harapan pelanggan dengan persepsi manajemen. Gap 2 menghubungakan antara persepsi manajemen dan spesifikasi kualitas pelayanan. Gap 3 mengaitkan spesifikasi kualitas dengan penyelenggaraan pelayanan. Gap 4 memperlihatkan gap yang terjadi antara penyelenggaraan pelayanan dengan komunikasi eksternal. Gap 5 membandingkan antara harapan pelayanan yang didapatkan oleh pelanggan dengan kinerja layanan jasa. Penelitian ini hanya mengukur Gap 5 karena Gap 5 dianggap sebagai gabungan dari keempat Gap yang lainnya (Parasuraman et al., 1985). Gap Score diperoleh dari hasil perhitungan sebagai berikut.

\section{Customer Perceived - Customer Expectaction = Gap Score}

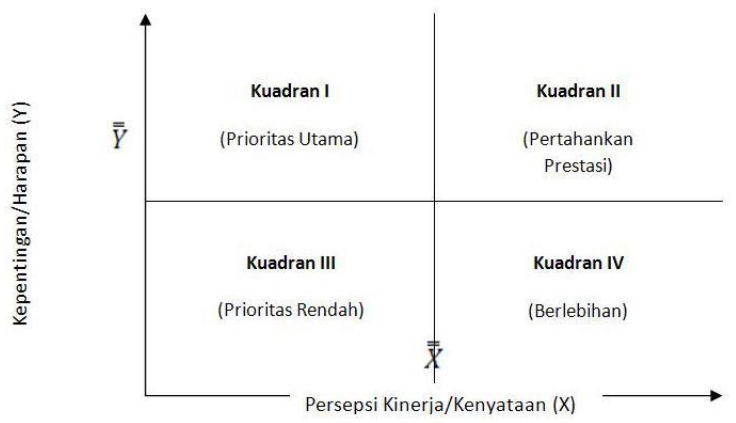

Sumber: Martilla dan James dalam Algifari, 2016

Gambar 4. Diagram Kartesius Importance-Performane Analysis

Gap Score positif (+) menunjukkan skor persepsi lebih besar dibandingkan dengan skor harapan, sedangkan jika skor persepsi lebih kecil dibandingkan dengan skor harapan maka akan diperoleh Gap Score negatif (-). Apabila gap yang dihasilkan dari perhitungan tersebut positif maka pelanggan dianggap sangat puas dengan pelayanan yang diberikan perusahaan tersebut. Sebaliknya jika gap negatif maka pelanggan merasa kurang/tidak puas dengan pelayanan yang didapatkan. Gap yang semakin kecil akan menunjukkan perusahaan tersebut memiliki kualitas pelayanan yang baik. (Irawan, 2002).

Gap Analysis (Importance-Performance Analysis (IPA)) adalah metode yang digunakan untuk mengukur dan mengetahui kesenjangan (gap) antara kinerja organisasi dengan harapan pelanggan. Metode ini diperkenalkan oleh Martilla dan James (1977) yang bertujuan untuk memudahkan menganalisis atribut-atribut yang didasarkan pada prioritas peningkatan kualitas produk atau jasa yang disebut pula sebagai quadrant analysis. Gambar 4 menggambarkan bentuk diagram kartesius dari IPA. 
Diagram ini terdiri dari empat kuadran, menurut Algifari (2016) kuadran I menjelaskan bahwa pelanggan menganggap atribut/pernyataan tersebut penting tetapi pada kenyataannya atribut tersebut belum sesuai dengan harapan pelanggan. Dengan demikian, perusahaan harus berkonsentrasi dan memperbaiki kinerjanya. Kuadran II menjelaskan perusahaan telah memberikan pelayanan terbaiknya kepada pelanggan berdasarkan atribut yang dianggap penting untuk pelanggan, kuadran ini menunjukkan kinerja yang baik dan perlu dipertahankan. Kuadran III menunjukkan kinerja perusahaan yang biasa saja atau dinilai kurang baik oleh pelanggan. Kuadran IV atribut atau pernyataan ini mempunyai tingkat harapan pelanggan yang rendah akan tetapi perusahaan memiliki kinerja yang baik, sehingga dianggap berlebihan oleh pelanggan.

Menurut Nguyen (2014:10) kualitas pelayanan yang baik tentunya tidak hanya berfokus pada mengembangkan suatu produk tetapi harus berfokus juga terhadap kualitas jaringan (network quality) dan keunggulan kompetitif (competitive advantage) untuk menghadapi persaingan dalam sektor telekomunikasi yang semakin ketat. Sedangkan menurut Baruah dkk (2015:112) serta Wang \& HingPo lo (2002:52) berpendapat bahwa network quality adalah salah satu faktor penting yang berhubungan dengan kualitas pelayanan dalam sektor telekomunikasi. Sedangkan menurut Johnson dan Anuchit (2002:693) berpendapat bahwa perusahaan akan mencapai profit yang tinggi dan pelayanan yang baik dibandingkan pesaingnya dengan menyiapkan keunggulan kompetitif tertentu kepada pelanggannya.

Oleh karena itu dalam mengukur kualitas pelayanan terdapat dua tambahan dimensi yaitu network quality dan competitive advantage agar setidaknya sesuai dengan kondisi objek penelitian di lapangan. Sehingga dimensi kualitas pelayanan menurut Parasuraman (1988:23) dan ditambah dengan dua dimensi yang dianggap penting dalam sektor telekomunikasi adalah sebagai berikut.

1. Bukti Fisik (Tangibles), bukti fisik adalah alat-alat yang digunakan untuk menunjang fasilitas pelayanan, sumber daya manusia yang dapat melayani dengan ramah dan sopan, serta materi komunikasi perusahaan.

2. Empati (Empathy), rasa yang timbul karena penyedia layanan memahami situasi yang dialami oleh pelanggan kemudian memberikan perhatian personal agar terkontrol setiap saat.

3. Kehandalan (Reliability), suatu kemampuan yang dimiliki oleh suatu perusahaan untuk menyampaikan layanan yang dijanjikan secara akurat sejak pertama kali.

4. Daya Tanggap (Responsiveness), hal ini mengenai kesediaan dan kemampuan penyedia layanan untuk membantu para pelanggan dan merespons permintaan mereka dengan segera. Kecepatan dan kepekaan penyedia layanan dapat mengukur sebaik apakah kualitas layanan di suatu perusahaan.

5. Jaminan (Assurance), berkaitan dengan kesopanan dan keamanan yang menumbuhkan rasa percaya diri penyedia layanan dan keyakinan pelanggan terhadap produk yang akan dibeli.

6. Kualitas Jaringan (Network Quality), seberapa bagus dan baiknya suatu jaringan yang dimiliki produk.

7. Keunggulan Kompetitif (Competitive Advantage), berfokus pada harga yang lebih murah atau mampu bersaing, pelayanan lebih baik dan promosi yang menarik dibandingkan pesaingnya.

\subsection{Kepuasan Pelanggan}

Kepuasan pelanggan menurut Tjiptono dan Anastasia (2015) adalah hal yang paling penting mencerminkan keberhasilan suatu usaha dari segi pemasaran. Suatu usaha dapat dikatakan berhasil apabila pelanggan menyatakan puas atas produk maupun layanan yang diberikan serta dapat mencapai tujuan organisasi yaitu mendapatkan laba, meningkatkan penjualan, mendapatkan pang sa pasar yang lebih besar, pertumbuhan usaha yang baik dari tahun ke tahun, kemudian dapat menyaingi persaingan bisnis dalam bidang yang sama. Sedangkan menurut Zeithamal dan Bitner (dalam Lupiyoadi dan Hamdani, 2013) yang mengatakan kepuasan pelanggan merupakan pandangan pelanggan terhadap kualitas pelayanan yang diberikan perusahaan.

Adapun menurut Kotler \& Keller (2009:138) mengemukakan bahwa "Kepuasan (satisfaction) adalah perasaan senang seseorang yang timbul karena membandingkan kinerja yang dipersepsikan produk (atau hasil) terhadap ekspektasi mereka". Pelanggan akan merasa puas apabila perusahaan memberikan pelayanan sesuai dengan harapan pelanggan sehingga tidak akan menimbulkan rasa kecewa bagi pelanggan tersebut.

Menurut Gronroos (Nguyen:2014) mengemukakan bahwa kepuasan pelanggan dapat diukur melalui kualitas pelayanan. Semakin mendekatinya harapan kualitas pelayanan dengan pelayanan yang 
dirasakan pelanggan, maka semakin besar pelanggan tersebut merasa puas dengan pelayanan yang diberikan perusahaan.

Berdasarkan beberapa pendapat dan definisi dari para ahli maka dapat disimpulkan bahwa kualitas pelayanan adalah jasa yang diberikan oleh perusahaan dapat sesuai dengan harapan pelanggan. Pelanggan akan merasa senang dari hasil membandingkan harapannnya dan persepsinya mengenai suatu layanan, sedangkan sebaliknya jika harapannya tidak sesuai dengan persepsi pelanggan terhadap layanan yang diterima maka pelanggan akan merasa kecewa.

Mengukur kepuasan pelanggan dapat dilakukan dengan menggunakan metode Nordic Model yang diperkenalkan oleh Gronroos $(1982,1984)$ ia mengukur kepuasan pelanggan berdasarkan pada dua kualitas pelayanan yaitu technical quality (apa yang diterima pelanggan) dan functional quality (bagaimana pelayanan yang diterima pelanggan). Model Nordic didasarkan pada diskonfirmasi paradigma dengan membandingkan kinerja yang dirasakan dan layanan yang diharapkan pelanggan. Ini adalah upaya pertama untuk mengukur suatu kualitas layanan. Model Gronroos bersifat umum dan tanpa menawarkan teknik apapun untuk mengukurnya.

Dimensi dalam model Nordic ini menurut Richters \& Rvorak dalam Nguyen (2014: 52) terdiri dari dua yaitu technical quality dan functional quality). Berikut ini adalah pemaparan mengenai masingmasing dimensi tersebut.

1. Technical Quality

Dimensi ini akan mengukur kepuasan pelanggan mengenai kualitas pelayanan secara keseluruhan serta produk yang digunakan, termasuk profesionalisme dan keterampilan suatu perusahaan dalam melayani pelanggan.

2. Functional Quality

Kualitas fungsional akan memberikan gambaran tentang bagaimana cara tersebut akan memberikan pengaruh pada persepsi pelanggan atas pelayanan yang diterima, apakah dapat memenuhi harapan pelanggan atau tidak. Dalam dimensi ini ada 4 indikator yaitu availabiliity, security, flexibility, simplicity dan semuanya terkait proses serta mewakili dimensi kualitas fungsional (Gronroos 1988: 13).

Menurut Gronroos (1984: 43) kedua dimensi tersebut saling berkaitan, kualitas teknis yang diterima dapat dianggap sebagai prasyarat untuk menghasilkan kualitas fungsional yang baik. Gronroos (1984: 41) menemukan bahwa, selama dimensi kualitas teknis setidaknya memuaskan pelanggan, kualitas fungsional dianggap lebih penting untuk mengukur kualitas layanan yang dirasakan secara keseluruhan.

Gambar 5 menunjukkan kerangka pemikiran dari penelitian ini. Pada dasarnya ada 5 (lima) hal yang mempengaruhi kualitas pelayanan, yaitu reliability, responsiveness, assurance, empathy dan tangible menurut Parasuraman at. al $(1985,1988)$ dalam Tjiptono (2014). Sedangkan penelitian yang dilakukan oleh Abdulrahman Al-Aali et al (2011) dan Baruah et al (2015) dengan mengadopsi dimensi yang digunakan oleh Johnson and Sirikit (2002), Wang et al (2004) dan Pezeshki et al (2009) maka ditambahkan dua dimensi yaitu network quality dan competitive advantage untuk mengukur kualitas pelayanan dalam sektor telekomunikasi. Kemudian dalam penelitian ini untuk mengukur kualitas

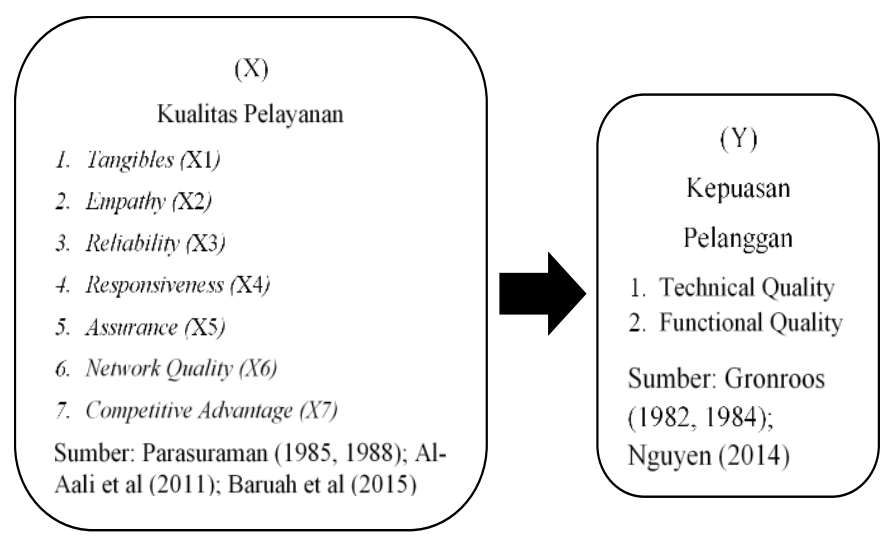

Gambar 5. Kerangka Pemikiran 
pelayanan menggunakan 7 dimensi yaitu reliability, responsiveness, assurance, empathy, tangible, network quality, dan competitive advantage. Hasil dari penilaian terhadap ketujuh dimensi tersebut, diharapkan dapat digunakan pihak manajemen Grapari Plasa Supratman PT Telekomunikasi Indonesia dalam mengetahui tanggapan dari pelanggan tentang kualitas pelayanan yang telah diberikan.

Berdasarkan latar belakang, landasan teori, dan kerangka berpikir, maka formulasi hipotesis yang diajukan untuk diuji kebenarannya dalam penelitian yang dilaksanakan, yaitu:

H0: Kualitas Pelayanan tidak berpengaruh terhadap Kepuasan Pelanggan Indihome di Grapari Plasa Supratman PT Telekomunikasi Indonesia Divisi Regional III Jawa Barat.

Ha: Kualitas Pelayanan berpengaruh terhadap Kepuasan Pelanggan Indihome di Grapari Plasa Supratman PT Telekomunikasi Indonesia Divisi Regional III Jawa Barat.

\section{Metode}

Service quality menjadi variabel bebas sedangkan variabel terikatnya adalah kepuasan pelanggan. Pada gambar 3 variabel bebas diukur menggunakan dimensi dari Parasuraman, Al-Ali dan Baruah sedangkan variabel terikat diukur menggunakan dimensi dari Gronroos dan Nguyen dengan menggunakan 5 skala likert.

Jumlah populasi tidak menentu karena dalam penelitian ini responden yang diperlukan adalah pelanggan yang berlangganan Indihome dan mengunjungi Grapari Plasa Supratman dan sampelnya berjumlah 100 diambil dari penentuan jumlah sampel menggunakan kuota. Data primer diperoleh dari hasil pra penelitian dan kuesioner. Sebagai pengetahuan, data sekunder diperlukan untuk menjawab masalah penelitian yang didapat dari buku dan jurnal.

Kuesioner diuji terlebih dahulu validitas dan reliabilitasnya sebelum disebarkan. Metode yang digunakan untuk menguji validitas pada penelitian ini adalah menggunakan metode Corrected ItemTotal Correlation. Seluruh indikator dinyatakan valid karena nilai yang ada pada kolom $R$ hitung $>R$ table $(0,1966)$. Sedangkan nilai cronbach alpha's lebih tinggi dari 0,6 sehingga pernyataaanpernyataan dalam kuesioner dapat dikatakan reliabel atau handal. Setelah semua pernyataan dalam kuesioner dinyatakan valid dan reliabel, kemudian data diujikan secara statistik menggunakan uji deksriptif, regresi, analisis gap, dan analisis kuadran (importance-performance analysis).

\section{Hasil dan Pembahasan}

\subsection{Identitas Responden}

Tabel 1. Identitas Responden

\begin{tabular}{lcc}
\hline \multicolumn{1}{c}{ Variabel } & Frekuensi & Persentase (\%) \\
\hline Jenis Kelamin & & \\
Pria & 43 & $43 \%$ \\
Wanita & 57 & $57 \%$ \\
\hline Usia & 3 & \\
$<18$ tahun & 46 & $3 \%$ \\
$18-25$ tahun & 20 & $46 \%$ \\
$26-35$ tahun & 31 & $20 \%$ \\
$>35$ tahun & & $31 \%$ \\
\hline Pekerjaan & 2 & \\
Guru & 6 & $2 \%$ \\
Ibu Rumah Tangga & 31 & $6 \%$ \\
Mahasiswa & 17 & $31 \%$ \\
Pegawai Negeri & 33 & $17 \%$ \\
Pegawai Swasta & 3 & $33 \%$ \\
Pelajar & 8 & $3 \%$ \\
Wiraswasta & & $8 \%$ \\
\hline
\end{tabular}




\begin{tabular}{lcc}
\hline Penghasilan & & \\
$<$ Rp 500.000 & $\mathbf{9}$ & $\mathbf{9 \%}$ \\
Rp 500.001 - Rp 1.000.000 & $\mathbf{1 2}$ & $\mathbf{1 2 \%}$ \\
Rp 1.000.001 - Rp 1.500.000 & $\mathbf{1 1}$ & $\mathbf{1 1 \%}$ \\
Rp 1.500.001 - Rp 2.000.000 & $\mathbf{1 3}$ & $\mathbf{1 3 \%}$ \\
$>$ Rp 2.000.000 & $\mathbf{5 5}$ & $\mathbf{5 5 \%}$ \\
\hline Lamanya Berlangganan & & \\
1 bulan & & $4 \%$ \\
2 bulan & 4 & $7 \%$ \\
3 - 5 bulan & 7 & $17 \%$ \\
$>5$ bulan & 17 & $72 \%$ \\
\end{tabular}

Tabel 1. Menunjukan identitas responden dalam penelitian ini. Data tersebut menunjukkan bahwa $57 \%$ responden adalah wanita dan responden pria sebesar $43 \%$. Kemudian, $46 \%$ responden berumur 18 - 25 tahun. Data tersebut juga menunjukkan bahwa 33\% responden bekerja sebagai pegawai swasta. Lalu dari segi penghasilan, 55\% responden memiliki penghasilan sebesar $>$ Rp 2.000.000. Dari segi lamanya berlangganan $72 \%$ responden berlangganan selama lebih dari 5 bulan.

\subsection{Service Quality}

Berdasarkan Tabel 2 variabel service quality memiliki rata-rata yang menunjukkan angka ekspektasi sebesar 4,00 yang berada pada interval 3,41-4,20 dapat dikategorikan tinggi. Sedangkan nilai mean pada persepsi pelanggan menunjukkan kualitas pelayanan yang diterima pelanggan adalah sebesar 3,84 yang berada pada interval 3,41-4,20 dan dikategorikan baik. Nilai standar deviasi ekspektasi pelanggan pada variabel ini berada dibawah $20 \%$ yakni sebesar $19,87 \%(0,795 / 4,00 x 100 \%)$. Sedangkan nilai standar deviasi persepsi pelanggan dalam penelitian ini berada diatas $20 \%$ yaitu sebesar 20,46 $(0,786 / 3,84 \times 100 \%)$.

Tabel 2. Analisis Deskriptif Service Quality

\begin{tabular}{lccccc}
\hline \multirow{2}{*}{ Nama Dimensi } & \multirow{2}{*}{} & \multicolumn{2}{c}{ Ekspektasi } & \multicolumn{2}{c}{ Persepsi } \\
\cline { 3 - 6 } & & Mean & Std. Dev & Mean & Std. Dev \\
\hline Reliability & 100 & 4,42 & 0,705 & 4,34 & 0,712 \\
Assurance & 100 & 4,08 & 0,743 & 3,99 & 0,759 \\
Tangible & 100 & 4,02 & 0,791 & 3,93 & 0,777 \\
Emphaty & 100 & 3,93 & 0,796 & 3,78 & 0,756 \\
Responsiveness & 100 & 4,05 & 0,791 & 3,90 & 0,704 \\
Network Quality & 100 & 3,80 & 0,894 & 3,39 & 1,017 \\
Competitive Advantage & 100 & 3,72 & 0,847 & 3,57 & 0,778 \\
Service Quality & $\mathbf{1 0 0}$ & 4,00 & 0,795 & 3,84 & 0,786 \\
\hline
\end{tabular}

\subsection{Kepuasan Pelanggan}

Dalam tabel 3 dapat diketahui bahwa nilai mean untuk variabel kepuasan pelanggan adalah sebesar 3,70. Berdasarkan tabel interpretasi nilai pada bab 3, diketahui bahwa nilai tersebut termasuk ke dalam rentang 3,41-4,20 sehingga dikategorikan tinggi. Standar deviasi pada variabel ini menunjukkan nilai variansi sebesar 0,814 atau sebesar $22 \%$ dari nilai mean. Hal ini menandakan jawaban responden terhadap variabel kepuasan pelanggan ini cukup seragam. Nilai mean terendah berada pada dimensi technical quality dengan nilai mean sebesar 3,63. Sedangkan nilai mean tertinggi berada pada dimensi functional quality dengan nilai mean sebesar 3,74.

Tabel 3. Analisis Deskriptif Kepuasan Pelanggan

\begin{tabular}{lccc}
\hline \multicolumn{1}{c}{ Dimensi } & N & Mean & Std. Dev \\
\hline Functional Quality & 100 & 3,74 & 0,781 \\
Technical Quality & 100 & 3,63 & 0,878 \\
Kepuasan Pelanggan & 100 & 3,70 & 0,814 \\
\hline
\end{tabular}




\subsection{Analisis Regresi Sederhana}

Berdasarkan tabel 4, diperoleh bahwa nilai konstanta (a) sebesar 2,587 dan nilai koefisien regresi (b) sebesar 0,323. Maka dari itu diperoleh persamaan regresi sebagai berikut: $Y=2,587+0,323 X$. Berdasarkan persamaan regresi linier sederhana tersebut, dapat diketahui bahwa setiap penambahan satu angka service quality dengan koefisien regresi bernlai positif, maka kepuasan pelanggan akan meningkat sebesar 0,323. Sedangkan, apabila service quality sama dengan nol atau tidak ada perubahan, maka nilai kepuasan pelanggan sebesar 0,323 .

Tabel 4. Uji Regresi Sederhana

\begin{tabular}{|l|l|l|}
\hline & Service Quality & \multicolumn{1}{|c|}{ Kepuasan Pelanggan } \\
\hline Service Quality & 1 & $0,733^{* *}$ \\
\cline { 2 - 3 } Sig. (2-Tailed) N & & 0,000 \\
\cline { 2 - 3 } & 100 & 100 \\
\hline $\begin{array}{l}\text { Kepuasan Pelanggan } \\
\text { Sig. (2- Tailed) N }\end{array}$ & $0,733^{* *}$ & 1 \\
\cline { 2 - 3 } & 0,000 & 100 \\
\cline { 2 - 3 } & 100 & \\
\hline
\end{tabular}

\subsection{Analisis Korelasi}

Berdasarkan Tabel 5, dapat dilihat jika mengacu pada interpretasi nilai hasil analisis korelasi menurut Bungin (2010: 184), maka nilai korelasi sebesar 0,733 termasuk ke dalam interval 0,70 ke atas yang artinya terdapat hubungan positif yang sangat kuat (very strong). Nilai korelasi pada tabel 4 'menunjukkan nilai positif, yang artinya jika service quality meningkat maka akan diikuti oleh peningkatan kepuasan pelanggan pula.

Tabel 5. Uji Korelasi

\begin{tabular}{|c|c|c|c|c|c|}
\hline \multicolumn{6}{|c|}{ Coefficients $^{\mathrm{a}}$} \\
\hline \multirow[t]{2}{*}{ Model } & $\begin{array}{l}\text { Unstanc } \\
\text { Coeffi }\end{array}$ & $\begin{array}{l}\text { dized } \\
\text { ents }\end{array}$ & $\begin{array}{c}\text { Stand. } \\
\text { Coefficients }\end{array}$ & \multirow[t]{2}{*}{$\mathrm{t}$} & \multirow[t]{2}{*}{ Sig. } \\
\hline & B & Std. Error & Beta & & \\
\hline 1 (Constant) & 2,587 & 1,858 & & 1,393 & 0,167 \\
\hline SQ & 0,323 & 0,030 & 0,733 & 10,674 & 0,000 \\
\hline
\end{tabular}

Correlation is significant at the 0.01 level (2-tailed).

Berdasarkan Tabel 6, nilai dari koefisien determinasi (R Square $/ R^{2}$ ) adalah 0,538 . Hal itu berarti bahwa sebesar 0,538 atau $53,8 \%$ perubahan kepuasan pelanggan dapat dijelaskan oleh variabel service quality, sedangkan sisanya sebesar $46,2 \%$ dijelaskan oleh sebab-sebab atau faktor lain yang tidak diteliti.

Tabel 6. Uji Koefisien Determinasi

\begin{tabular}{|l|c|r|r|r|}
\hline \multicolumn{4}{|c|}{ Model Summary } \\
\hline Model & $\mathrm{R}$ & R Square & Adjusted R Square & Std. Error of the Estimate \\
\hline 1 & $0,733^{\mathrm{a}}$ & 0,538 & 0,533 & 2,63287 \\
\hline
\end{tabular}

a. Predictors: (Constant), Service Quality 


\subsection{Uji Hipotesis}

Berdasarkan Tabel 7, dapat dilihat bahwa angka significant pada kolom Sig. Adalah 0,000. Nilai tersebut lebih kecil dibandingkan dengan nilai probabilitasnya sebesar 0,05 (5\%). Apabila dilihat dari nilai $\mathrm{F}$ hitung $\left(F_{o}\right)$ yang terlihat pada kolom $\mathrm{F}$ yang besarnya 113,939 dengan menggunakan tingkat signifikansi 0,05 , maka diperoleh $\mathrm{F}$ tabel $\left(F_{1}\right)$ sebesar 3,94 yang berarti bahwa nilai $F_{o} \geq F_{1}$ yaitu $113,939 \geq 3$,94. Mengacu pada interpretasi hasil uji statistik F menurut Arikunto (2010: 268), jika kriteria $F_{o} \geq F_{1}$ dengan taraf signifikansi 5\% maka interpretasinya adalah $H_{o}$ ditolak dan $H_{a}$ diterima. Hal tersebut menunjukkan bahwa service quality berpengaruh secara positif dan signifikan terhadap kepuasan pelanggan.

Tabel 7. Uji F

\begin{tabular}{|c|l|c|c|c|}
\hline \multicolumn{2}{|c|}{ Model } & df & F & Sig. \\
\hline $\mathbf{1}$ & Regression & 1 & 113,939 & $0,000^{\mathrm{b}}$ \\
\hline & Residual & 98 & & \\
\hline & Total & 99 & & \\
\hline
\end{tabular}

Berdasarkan Tabel 8 diperoleh nilai $t$ hitung sebesar 10,674. Dengan rumus $\mathrm{df}=$ jumlah data -1 atau sebesar $100-1=99$, maka diperoleh $\mathrm{t}$ tabel 1,984. Berdasarkan data tersebut, diperoleh nilai $\mathrm{t}$ hitung yang lebih besar dari t tabel $(10,674>1,984)$. Angka signifikansi pada kolom Sig. Adalah 0,000, nilai tersebut lebih kecil dibandingkan dengan nilai probabilitasnya yang nilainya sebesar 0,05 atau $5 \%$ $(0,05>0,000)$. Maka dari itu mengacu pada pendapat Sugiyono (2012: 250) yang menyatakan bahwa jika kriteria $\mathrm{t}$ hitung $>\mathrm{t}$ tabel dan tingkat signifikansi $<0,05$, maka memiliki arti bahwa $H_{o}$ ditolak dan $H_{a}$ diterima. Hal tersebut menunjukkan servie quality berpengaruh secara positif dan signifikan terhadap kepuasan pelanggan.

Tabel 8. Uji T

\begin{tabular}{|l|l|c|c|}
\hline \multicolumn{2}{|c|}{ Model } & t & Sig. \\
\hline $\mathbf{1}$ & (Constant) & 1,393 & 0,167 \\
\hline & Service Quality & 10,674 & 0,000 \\
\hline
\end{tabular}

\subsection{Pembahasan}

Pada tabel 9 dapat dilihat bahwa dari ketujuh dimensi pada service quality, dimensi Competitive Advantage merupakan dimensi dengan ekspektasi terendah tingkat kepentingannya oleh pelanggan, dengan nilai mean yang didapatkan sebesar 3,71. Dimensi Competitive Advantage atau keunggulan kompetitif dianalisis menggunakan tiga indikator yakni harga, kualitas pelayanan yang diberikan, dan paket promo. Sedangkan dimensi Reliability merupakan dimensi dengan nilai ekspektasi tertinggi atau dinilai memiliki tingkat kepentingan yang tinggi oleh pelanggan yakni sebesar 4,42. Dari segi persepsi, dimensi Network Quality merupakan dimensi yang dinilai paling rendah kinerjanya oleh para pelanggan. Hal ini ditandai dengan nilai mean yang didapatkan oleh dimensi Network Quality yang lebih rendah dibandingkan dengan dimensi lainnya, yaitu sebesar 3,39. Sedangkan dimensi yang dinilai oleh pelanggan tinggi kinerjanya yaitu dimensi Reliability, dengan perolehan nilai mean sebesar 4,34.

Tabel 9. Analisis Gap

\begin{tabular}{|l|c|c|c|c|}
\hline \multicolumn{1}{|c}{ Dimensi } & $\begin{array}{c}\text { Kode } \\
\text { Item }\end{array}$ & $\begin{array}{c}\text { Rata-rata Ekspektasi } \\
\text { Konsumen (E) }\end{array}$ & $\begin{array}{c}\text { Rata-rata Persepsi } \\
\text { Konsumen (P) }\end{array}$ & $\begin{array}{c}\text { Servqual } \\
\text { Score }\end{array}$ \\
\hline \multirow{2}{*}{ Tangibles } & T1 & 4,43 & 4,37 & $-0,06$ \\
\cline { 2 - 5 } & T2 & 4,40 & 4,30 & $-0,10$ \\
\hline Rata-Rata & & $\mathbf{4 , 4 2}$ & $\mathbf{4 , 3 4}$ & $\mathbf{- 0 , 0 8}$ \\
\hline \multirow{2}{*}{ Empathy } & E3 & 4,04 & 4,04 & 0,00 \\
\cline { 2 - 5 } & E4 & 4,11 & 3,93 & $-0,18$ \\
\hline Rata-Rata & & $\mathbf{4 , 0 8}$ & $\mathbf{3 , 9 9}$ & $-\mathbf{0 , 0 9}$ \\
\hline Responsiveness & R5 & 4,10 & 3,96 & $-0,14$ \\
\cline { 2 - 5 } & R6 & 3,94 & 3,89 & $-0,05$ \\
\hline Rata-Rata & & $\mathbf{4 , 0 2}$ & $\mathbf{3 , 9 3}$ & $\mathbf{- 0 , 0 9}$ \\
\hline
\end{tabular}




\begin{tabular}{|l|c|c|c|c|}
\hline \multirow{2}{*}{ Reliability } & RE7 & 3,85 & 3,68 & $-0,17$ \\
\cline { 2 - 5 } & RE8 & 4,01 & 3,87 & $-0,14$ \\
\hline Rata-Rata & & $\mathbf{3 , 9 3}$ & $\mathbf{3 , 7 8}$ & $\mathbf{- 0 , 1 6}$ \\
\hline \multirow{2}{*}{ sssurance } & $\mathrm{A} 9$ & 4,00 & 3,84 & $-0,16$ \\
\cline { 2 - 5 } & $\mathrm{A} 10$ & 4,09 & 3,95 & $-0,14$ \\
\hline Rata-Rata & & $\mathbf{4 , 0 5}$ & $\mathbf{3 , 9 0}$ & $\mathbf{- 0 , 1 5}$ \\
\hline \multirow{4}{*}{ Network Quality } & $\mathrm{N} 11$ & 3,58 & 3,04 & $-0,54$ \\
\cline { 2 - 5 } & $\mathrm{N} 12$ & 3,75 & 3,11 & $-0,64$ \\
\cline { 2 - 5 } & $\mathrm{N} 13$ & 4,08 & 4,02 & $-0,06$ \\
\hline Rata-Rata & & $\mathbf{3 , 8 0}$ & $\mathbf{3 , 3 9}$ & $-\mathbf{0 , 4 1}$ \\
\hline \multirow{2}{*}{ Advanpetitive } & $\mathrm{C} 14$ & 3,60 & 3,53 & $-0,07$ \\
\cline { 2 - 5 } & $\mathrm{C} 15$ & 3,82 & 3,67 & $-0,15$ \\
\cline { 2 - 5 } & $\mathrm{C} 16$ & 3,74 & 3,51 & $-0,23$ \\
\hline Rata-Rata & & $\mathbf{3 , 7 2}$ & $\mathbf{3 , 5 7}$ & $\mathbf{- 0 , 1 5}$ \\
\hline
\end{tabular}

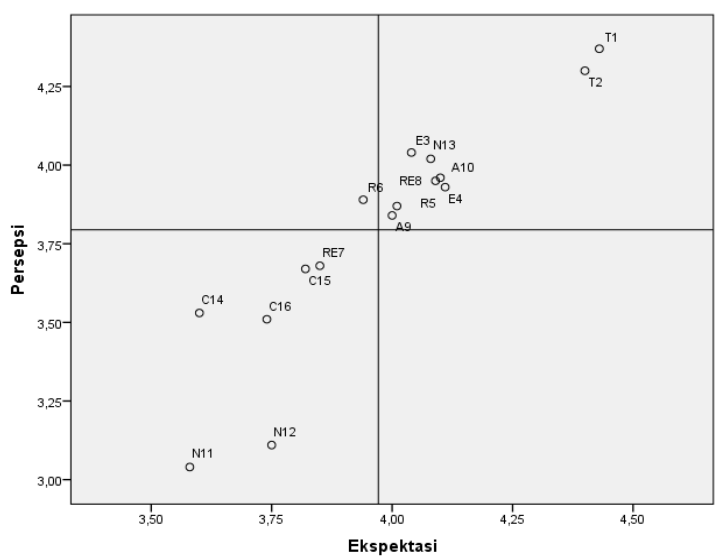

Gambar 6. Grafik Importance Performance Analysis

Pada tabel 9 dapat terlihat juga bahwa seluruh indikator yang berada pada variabel service quality bagian persepsi memiliki nilai mean yang berada pada interval rata-rata dengan kategori baik. Sedangkan dari segi ekspektasi, seluruh dimensi service quality dinilai memiliki tingkat kepentingan yang sangat tinggi. Sehingga dapat disimpulkan bahwa ekspektasi pelanggan terhadap layanan Grapari Telkom Supratman masih belum terpenuhi. Walaupun dalam segi layanan sudah mendapat penilaian yang baik oleh para pelanggan. Dari seluruh indikator service quality, indikator N12 yaitu cakupan sinyal internet yang luas memiliki nilai gap yang paling tinggi yakni -0,64. Sedangkan indikator E3 yaitu indikator jam layanan dan R6 yaitu_customer service memberitahukan kapan pelanggan akan dilayani adalah indikator dengan gap paling rendah.

Gambar 6 menjelaskan tentang gambaran matriks yang digunakan untuk menganalisis kinerja service quality yang diterima oleh pelanggan serta kinerja service quality yang dianggap penting oleh pelanggan. Berikut ini adalah uraian mengenai gambar tersebut.

Pada kuadran A terdapat indikator R6 yakni indikator customer service memberitahukan kapan pelanggan akan dilayani (dimensi responsiveness). Artinya dimensi responsiveness dianggap penting oleh pelanggan, tetapi PT Telekomunikasi Indonesia Divre III Jawa Barat di Grapari Plasa Supratman memberikan pelayanan yang kurang baik. Oleh karena itu, manajemen Grapari Plasa Supratman perlu meningkatkan pelayanan yang prima kepada para pelanggan dari indikator ini.

Pada kuadran B terdapat indikator T1, T2, E3, E4, R5, RE8, A9, A10, dan N13. Indikator tersebut adalah ruang tunggu nyaman dan bersih, fasilitas yang modern, jam layanan, customer service mengetahui kebutuhan pelanggan, saat sibuk tetap melayani dengan cepat, customer service cepat dan tanggap, customer service dapat dipercaya, merasa aman saat bertransaksi, dan sering terjadinya gangguan. Kuadran B memiliki arti bahwa pelanggan menilai indikator-indikator tersebut penting dan kualitas yang diberikan oleh PT Telekomunikasi Indonesia Divisi Regional III Jawa Barat di Grapari 
Plasa Supratman dinilai baik. Manajemen Grapari Plasa Supratman perlu mempertahankan kualitas pelayanan yang diberikan kepada pelanggan untuk indikator-indikator ini.

Kuadran C terdapat indikator RE7, N11, N12, C14, C15, dan C16. Indikator tersebut yakni, pelayanan perusahaan dapat diandalkan, sinyal internet stabil dan lancar, cakupan sinyal internet yang luas, harga yang mampu bersaing, kualitas pelayanan yang lebih baik dibanding pesaing, paket promo yang lebih menarik. Pada kuadran $\mathrm{C}$ pelanggan menilai indikator-indikator tersebut kurang begitu penting oleh pengguna layanan Indihome dan pelayanan yang diberikan kurang memuaskan. Oleh karena itu, manajemen Grapari Plasa tidak memperhatikan indikator kualitas pelayanan ini sehingga layanan yang diberikan tidak memenuhi harapan pelanggan. Atau dengan kata lain, atribut ini bukan merupakan prioritas, melainkan perlu dijadikan pendukung dalam layanan yang diberikan oleh PT Telekomunikasi Indonesia.

Tidak terdapat indikator yang berada di kuadran D. Artinya pada kuadran ini, pelayanan yang diberikan tinggi atau berlebihan dan indikatornya dianggap kurang penting. Indikator-indikator dalam penelitian ini tidak termasuk ke dalam kuadran D. Pihak manajemen Grapari Plasa Supratman perlu meningkatkan usaha atau prioritas dalam memberikan pelayanan yang baik dan meningkatkan usaha perbaikan pelayanan indikator di kuadran A.

Analisis deskriptif variabel kepuasan pelanggan digunakan untuk menjawab rumusan masalah kedua, bagaimana kepuasan pelanggan Indihome di Grapari Plasa Supratman PT Telekomunikasi Indonesia. Berdasarkan hasil perhitungan spss, diperoleh bahwa kepuasan pelanggan Grapari Plasa Supratman sudah tergolong baik. Hal tersebut dapat dilihat dari nili mean yang diperoleh dari jawaban responden yaitu 3,69. Pernyataan tersebut disetujui oleh sebagian besar responden yang ditunjukkan oleh nilai standar deviasi yang berada di atas $20 \%$ dari nilai mean yaitu sebesar $21,96 \%$, yang memiliki arti bahwa hampir keseluruhan responden menjawab serupa. Mean tertinggi berada pada pernyataan "prosedur berlangganan dipermudah dan dipercepat."

Berdasarkan pengertiannya, kepuasan pelanggan menurut Kotler \& Keller (2014:150) adalah perasaan senang seseorang yang timbul karena membandingkan kinerja yang dipersepsikan atau diterima setidaknya sesuai dengan harapan mereka. Berdasarkan hal tersebut, dapat disimpulkan bahwa meskipun PT Telekomunikasi Indonesia merupakan satu-satunya BUMN yang bergerak di bidang telekomunikasi dan jaringan, harapan pelanggan atas kualitas pelayanan yang didapatkan belum terpenuhi. Namun, dari keseluruhan responden yang menggunakan Indihome dan mengunjungi Grapari Plasa Supratman mengatakan cukup puas dengan pelayanan yang diberikan. Tetapi PT Telekomunikasi harus terus melakukan perbaikan-perbaikan kualitas layanan, seperti mengurangi gangguan yang sering terjadi sehingga tidak merugikan pelanggan. Dengan adanya Grapari Plasa Supratman, memudahkan pelanggan untuk menyampaikan keluhannya tentang produk Indihome. Namun, untuk menghadapi persaingan di industri telekomunikasi PT Telekomunikasi Indonesia harus terus meningkatkan kualitas layanannya sehingga pelanggan akan merasa puas, jika tidak maka kepuasan pelanggan terhadap kualitas layanan Grapari Plasa Supratman akan menurun.

Pembahasan pada bagian ini bertujuan untuk menjawab rumusan permasalahan yang ketiga yakni, bagaimana pengaruh kualitas pelayanan terhadap kepuasan pelanggan Indihome di Grapari Plasa Supratman PT Telekomunikasi Indonesia. Berdasarkan hasil perhitungan SPSS pada 100 orang pelanggan Indihome yang mengunjungi Grapari Plasa Supratman diperoleh hasil bahwa terdapat pengaruh antara variabel service quality dan kepuasan pelanggan. Hal itu dapat dilihat berdasarkan analisis regresi yang dilakukan, dapat diketahui bahwa variabel service quality memiliki pengaruh yang positif dan signifikan terhadap kepuasan pelanggan. Hal tersebut dapat dilihat dari persamaan $\mathrm{Y}=2,587$ $+0,323 \mathrm{X}$. Berdasarkan persamaan regresi tersebut, dapat diketahui bahwa setiap penambahan satu angka service quality dengan koefisien regresi bernlai positif, maka kepuasan pelanggan akan meningkat sebesar 0,323. Sedangkan, apabila service quality sama dengan nol atau tidak ada perubahan, maka nilai kepuasan pelanggan sebesar 0,323.

Kualitas pelayanan berpengaruh terhadap kepuasan pelanggan. Hal tersebut didukung oleh hasil penelitian yang menunjukkan service quality berpengaruh positif dan signifikan terhadap kepuasan pelanggan. Adapun besarnya pengaruh service quality terhadap kepuasan pelanggan yakni, sebesar 0,538 atau $53,8 \%$ perubahan kepuasan pelanggan dapat dijelaskan oleh variabel service quality, sedangkan sisanya sebesar 46,2\% dijelaskan oleh sebab-sebab atau faktor lain yang tidak diteliti. Oleh 
karena itu, jika perusahaan ingin meningkatkan kepuasan pelanggannya, maka perusahaan harus mampu meningkatkan mutu kualitas pelayanannya (service quality).

\section{Kesimpulan}

Berdasarkan hasil dari analisis dan pembahasan yang telah dipaparkan, maka dapat disimpulkan yang kemudian menjawab perumusan masalah sebagai berikut.

1. Persepsi dan ekspektasi dalam service quality yang dirasakan pelanggan Indihome yang mengunjungi Grapari Plasa Supratman secara keseluruhan dikategorikan tinggi.

2. Secara keseluruhan, kepuasan pelanggan Indihome yang mengunjungi Grapari Plasa Supratman berada pada kategori baik. Mean tertinggi berada pada pernyataan "prosedur berlangganan dipermudah dan cepat".

3. Terdapat pengaruh yang positif dan signifikan dari service quality terhadap kepuasan pelanggan pada Grapari Plasa Supratman. Service quality mempengaruhi kepuasan pelanggan sebesar 53,8\%, sedangkan sisanya 46,2\% dipengaruhi oleh faktor-faktor lain yang tidak diteliti. Berdasarkan hasil regresi linier sederhana diperoleh persamaan $\mathrm{Y}=2,587+0,323 \mathrm{X}$. Dengan demikian, jika terjadi penambahan atau peningkatan bobot pada service quality sebesar satu satuan, maka kepuasan pelanggan akan mengalami peningkatan pula.

\section{Daftar Pustaka}

Abdulrahman, A.-A., Khurshid, M. A., Nasir, N. M., \& Al-Aali, H. (2011). Measuring the Service Quality of Mobile Phone Companies in Saudi Arabia. Journal of Administration Science, Volume 22(Number 2), 43-55.

Algifari. (2016). Mengukur Kualitas Pelayanan (Cetakan ke 1 ed.). Yogyakarta: BPFE.

Arikunto, S. (2013). Prosedur Penelitian: Suatu Pendekatan Praktik. Jakarta: Rineka Cipta.

Baruah, D., Nath, T., \& Bora, D. (2015). Impact of Service Quality Dimensions on Customer Satisfaction in Telecom Sector. International Journal of Engineering Trends and Technology (IJETT), Volume 27(Number 2), 111-117.

Gronroos, C. (1982). An Applied Service Marketing Theory. European Journal of Marketing, Volume 16(Number 7), 30-41.

Gronroos, C. (1984). A Service Quality Model and Its Marketing Implications. European Journal of Marketing, Volume 18(Number 4), 36-44.

Gronroos, C. (1988). Service Quality: The Six Criteria of Good Perceived Service Quality. Review of Business. Journal of Service Management, Volume 9, 10-13.

Gummesson, E., \& Gronroos, C. (2012). The Emergence of the New Service Marketing: Nordic School Perspective. Journal of Service Management, Volume 23(Number 4), 479-497.

Heriza, A. F., \& Wartiningsih, E. (2015). Pengaruh Kualitas Pelayanan Terhadap Kepuasan Pelanggan pada PT. Telkom Witel Jakarta Selatan. Jurnal Administrasi Bisnis Terapan, Administrasi Niaga, Volume 12(Number 2), 79-83.

Ibrahim, M., Nyame, R., \& Kumah, A. (2014). Quality Service Delivery Among Telecommunication Service Operators in Ghana: A Case of Vodafone-Ghana. International Journal of Economics, Commerce, and Management, Volume 2(Number 5), 1-18.

Johnson, W. C., \& Sirikit, A. (2002). Service Quality in the Thai Telecommunication Industry: a tool for achieving a sustainable competitive. Journal of Management Decision, Volume 40(Number 7), 693-701.

Lupiyoadi, R., \& A, H. (2013). Manajemen Pemasaran Jasa. Jakarta: Salemba Empat.

Martilla, J. A., \& James, J. C. (1977). Importance Performance Analysis. Journal of Marketing, Volume 41(Number 1), 77-79.

Nguyen, T. P. (2014). Measuring Customer Satisfaction on Perceived Service Quality: Case on Mobile Telecommunications Service of Bouygues Telecom, France. France: Degree Program in International Business.

Nugroho, N. T. (2015, Agustus). Pengaruh Kualitas Pelayanan Terhadap Kepuasan dan Loyalitas Pelanggan (Survey pada Pelanggan Speedy Telkom di Kota Surakarta). Jurnal Paradigma, Vol. 12, No. 02, 114-122. 
Parasuraman, A. P., Berry, L. L., \& Zeithaml, V. A. (1991). Refinement and reassesment of the SERVQUAL scale. Journal of Retailing, Volume 67(Number 4), 420-450.

Parasuraman, A., Zeithaml, V. A., \& Berry, L. L. (1985). A Conceptual Model of Service Quality and Its Implications for Future Reasearch. Journal of Marketing, 41-50.

Parasuraman, A., Zeithaml, V. A., \& Berry, L. L. (1988). Servqual: A Multiple-Item Scale for Measuring Consumer Perceptions of Service Quality. Journal of Retailing, Vol. 64, No. 01, 12-40.

Pezeshki, V., Mousavi, A., \& Grant, S. (2009). Importance-Performance Analysis of Service Attributes and Its Impact on Decision Making in the Mobile Telecommunication Industry. Journal of Measuring Business Excellence, Volume 13(Number 1), 82-92.

Putri, N. M., \& Arry, W. (2016, Desember). Pengaruh Kualitas Pelayanan terhadap Kepuasan Pelanggan Indihome pada Wilayah Antapani Kota Bandung. e-Proceeding of Management, Vol. 3, No. 03, 3596-3603.

Saputro, Y., Nining, L., \& dan Riza, H. (2016, Oktober). Pengaruh Kualitas Produk Indihome Telkom Terhadap Loyalitas Pelanggan di Forum Komunitas CS: GO Indonesia Community. Epigram, Vol. 13, No. 02, 143-151.

Sugiyono. (2017). Statistika untuk Penelitian. Bandung: Alfabeta.

Tjiptono, F. (2015). Pelanggan Puas? Tidak Cukup! Yogyakarta: ANDI.

Tjiptono, F., \& Gregorius, C. (2012). Pemasaran Strategik. Yogyakarta: ANDI.

Ulkhaq, M. M., \& Barus, M. P. (2017). Analisis Kepuasan Pelanggan dengan Menggunakan SERVQUAL: Studi Kasus Layanan Indihome PT Telekomunikasi Indonesia, Tbk, Regional 1 Sumatera. Jurnal Sistem dan Manajemen Industri, Volume 1(Number 2), 61-67.

Wang, Y., \& Lo, H.-P. (2002). Service Quality, Customer Satisfaction and Behavior Intentions: Evidence from China's Telecommunication Industry. Volume 4(Number 6), 50-60.

Wang, Y., Lo, P. H., \& Yang, Y. (2004). An Integrated Framework for Service Quality, Customer Value, Satisfaction: Evidence from China's Telecommunication Industry. Information Systems Frontiers, Volume 6 (Number 4), 25-40.

*Email korespondensi:

ayu.marluthy.abs414@polban.ac.id 